\title{
Rooting Responses of Miracle Fruit (Synsepalum dulcificum) Softwood Cuttings as Affected by Indole Butyric Acid
}

\author{
Xing Wei Chen, Thohirah Lee Abdullah, \\ Nur Ashikin Psyquay Abdullah and Siti Aishah Hassan
}

Department of Crop Science, Faculty of Agriculture, Universiti Putra Malaysia, 43400 UPM Serdang, Selangor, Malaysia

Received 2012-06-26, Revised 2012-07-06; Accepted 2012-12-4

\section{ABSTRACT}

Large scale productions of miracle fruit (Synsepalum dulcificum) faces some restrictions as the seeds are recalcitrant and propagation by cuttings is difficult to root. When grown from seed, miracle fruit takes 3 to 4 years to begin fruiting. A propagation technique by cuttings needs to be devised to produce early fruiting planting materials. However there has been no report on the rooting performance of miracle fruit stem cuttings using Indole-3-Butyric Acid (IBA) and the location of root primordia initiation is unknown. Softwood miracle fruit cuttings were treated with five IBA concentrations $\left(0,200,400,600\right.$ and $\left.800 \mathrm{mg} \mathrm{L}^{-1}\right)$ and placed in a propagation area with intermittent mist. Data for percentage of rooting (\%), mean root numbers per rooted cutting, mean root length per rooted cutting $(\mathrm{cm})$ and root dry weight per rooted cutting $(\mathrm{g})$ were collected 3 months after planting. Thirty softwood cuttings were propagated for histological study. The basal $5 \mathrm{~mm}$ of three cuttings were harvested randomly weekly. The specimens were sectioned and the cross sections were viewed to locate the root primordia initiation. Callus formation started three weeks after sowing and the adventitious roots emerged from the basal end eight weeks after planting. High concentration of IBA treatment was significantly increase the rooting percentage when compared with other treatments. Anatomy of stem $800 \mathrm{mg} \mathrm{L}^{-1}$ day 0 showed the phloem was surrounded by 2-3 layers of fibers. Root primordial developed from the secondary phloem and penetrated the fiber layers 5 weeks after planting. IBA concentrations gave little effect in roots initiation and development of miracle fruit. Root primordial was developed from the secondary phloem and surrounded by fiber layers was could hinder its emergence. However, IBA applications promoted cell expansion and proliferations which able to break the fiber layers and allowed the root primordial to emerge.

Keywords: Sapotaceae, Root Primordia, Fibers Layer

\section{INTRODUCTION}

Miracle fruit (Synsepalum dulcificum Daniell family: Sapotaceae) is a tropical evergreen shrub or small tree indigenous to tropical West Africa (Ayensu, 1972; Duke and DuCellier, 1993; Keay, 1992; Opeke, 1982). The plant can be found growing in partial shade area under the canopy of the rain-forest in its native habitat and is able to tolerate full sunshine and drought (Duke and DuCellier, 1993).

Miracle fruit tree produces small ellipsoid berries (2$3 \mathrm{~cm}$ long) throughout the year (Fig. 1A). The fruits turn bright red when ripe with a thin layer of edible pulp surrounding an elongate-ovoid shape seed. The seed coat is hard and smooth with dark brown to black colour (Fig. 1B). The most unusual thing about the fruit is the extraordinary effect of the fleshy pulp on the taste buds of the tongue that makes every sour or acidic food eaten or drunk to taste very sweet. The pulp contained miraculin, a glycoprotein which exhibits the tastemodifying activity when it reacts with acid substances in the mouth (Kant, 2005; Temussi, 2006). Miracle fruit could possibly help diabetic people in eating sweet food without taking in sugar and has been investigated as a possible source for a natural food sweetener (Kant, 2005).

Corresponding Author: Thohirah Lee Abdullah, Department of Crop Science, Faculty of Agriculture, Universiti Putra Malaysia, 43400 UPM Serdang, Selangor, Malaysia 

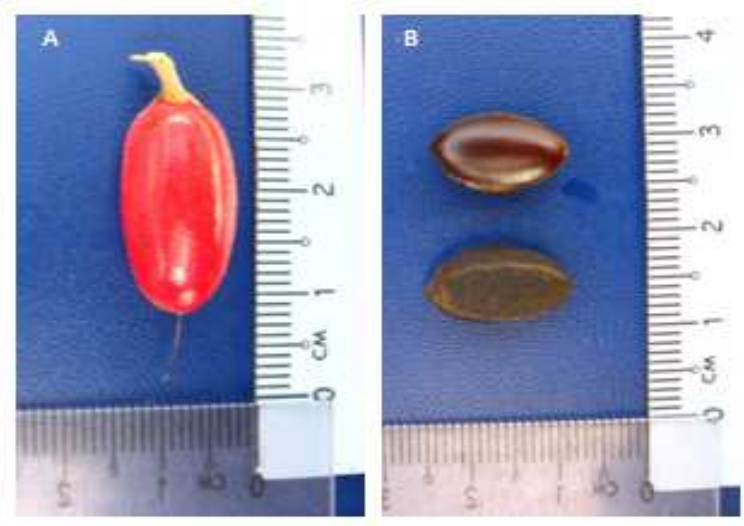

Fig. 1. Synsepalum dulcificum (Sapotaceae): (A) red ellipsoid ripen berry, (B) dark brown to black colour seeds with hard seed coat

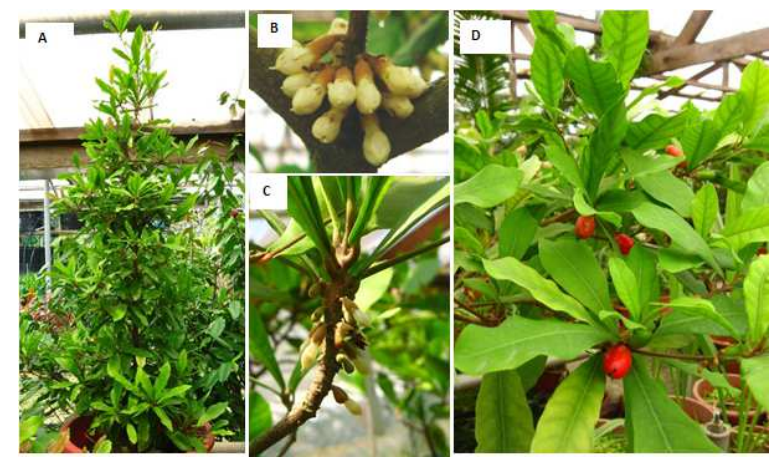

Fig. 2. Synsepalum dulcificum: (A) Pyramidal tree form, (B) flowers produced in cluster at the axillary bud, (C) downward-facing flowers are solitary, nearly sessile and fragrant, (D) a five years old plant with red berries

Miracle fruit has been cultivated not only for its fruit but also as an ornamental plant. The tree form of Synsepalum dulcificum is cone or pyramid shape (Fig. 2A). The moderate growth rate and free branching characteristic of this plant make it a potential ornamental small tree or shrub, hedges and potted plant for urban planting. Pruning is not necessary since it is bushy becoming a beautiful tree form naturally. Besides that, the miracle fruit plant also can be trained into a bonsai or topiary. Synsepalum dulcificum has red to orange colour young leaves which adds to the aesthetic value of the plant. The plant produces fragrance flowers (Fig. 2B and 2C) and edible fruits (Fig. 2D) all year round; thus it is a good candidate for a fragrant garden or edible garden. The miracle berries turn bright red when ripen and makes the tree a stunning and attractive ornamental plant. The plant also attracts birds to feed on its berries.
Large scale productions of miracle fruit faces some restrictions as the seeds are recalcitrant and propagation by cuttings is difficult to root. Most of the miracle fruit plants available in the market are grown by seeds but the growth of the seedlings is slow at nursery stage (Duke and DuCellier, 1993). A one year old plant often is only 5-7.5 $\mathrm{cm}$ tall and it takes 3 to 4 years for the plant to reach 35-50 $\mathrm{cm}$ tall and then growth is more rapid (Joyner, 2006). When grown from seed, Synsepalum dulcificum took 3 to 4 years to reach maturity and begin to bear fruit whereas plants grown from stem cuttings started to bear fruit earlier (Joyner, 2006). A propagation technique by cuttings needs to be devised to produce early fruiting planting materials (Duke and DuCellier, 1993). Auxins are well known phytohormone in promoting adventitious root from stem cuttings of tree species (Kesari et al., 2009). Indole-3-Butyric Acid (IBA) is the best synthetic auxin for general use because it is nontoxic to plants over a wide range of concentration (Hartman, 2002). Although IBA was proven effective in promoting rooting in woody plant species (Kesari et al., 2009) however there has been no report on the rooting performance of Synsepalum dulcificum stem cuttings using IBA. The objectives of this study are: to investigate the optimum IBA concentrations in promoting rooting of miracle fruit cuttings and to identify the location of root primordia initiation.

\section{MATERIALS AND METHODS}

One hundred and twenty five softwood miracle fruit cuttings measured 1 to $2 \mathrm{~cm}$ in length with 3 to 5 nodes and 3 to 4 leaves were collected 5 weeks after the tree flushes. The cut were made just below a node and treated with five IBA concentrations $\left(0,200,400,600\right.$ and $\left.800 \mathrm{mg} \mathrm{L}^{-1}\right)$ using the quick-dips method as mentioned by Hartman (2002). River sand was used as rooting media and treatments were arranged in a Randomized Complete Block Design (RCBD) with 5 cuttings in each treatment and replicated five times. A high humidity environment (70-90\% RH) with $90 \%$ shade was provided in the propagation area where intermittent mist was supplied for $15 \mathrm{~min}$ at $45 \mathrm{~min}$ intervals from 0700 to 1900 daily. Any flower buds that developed from the cuttings were removed throughout the experiment. Data were collected for percentage of rooting $(\%)$, mean root numbers per rooted cutting, mean root length per rooted cutting $(\mathrm{cm})$ and root dry weight per rooted cutting $(\mathrm{g})$ were collected 3 months after planting. Data in percentage was subjected to arcsine transform before analyzed with analysis of variance (ANOVA) using Statistical Analysis System (SAS) version 9.1 and means were separated by (SAS institute Inc. Cary, NC, USA). Thirty softwood cuttings were propagated for histological study. Three cuttings were harvested randomly weekly. The basal $5 \mathrm{~mm}$ of the cuttings were harvested and fixed in 
Formalin Acetic Acid (FAA) for 3 days. Specimens were processed according to the method developed by Johansen (1940). Specimens were placed in high pressure $(630 \mathrm{~mm}$ $\mathrm{Hg}$ ) vacuum oven for four hours and dehydrated in Tertiary Butyl-Alcohol (TBA) series. Wax infiltration was carried out and specimens were embedded before being sectioned with a rotary microtome. The specimens were sectioned into 8-10 $\mu \mathrm{m}$ thick and stained with Safranin O and Fast Green (FCF) dyes. Cross sections were viewed and recorded using a digital camera attached to an optical microscope under the control of computer.

\section{RESULTS}

Softwood cuttings began to form callus three weeks after planting and the adventitious roots emerged eight weeks after planting. Sparse fleshy adventitious roots arise from each rooted cuttings 3 months after planting (Fig. 3). High concentration of IBA $\left(800 \mathrm{mg} \mathrm{L}^{-1}\right)$ treatment increased the rooting percentage of softwood miracle fruit cuttings (Table 1). Cuttings treated with $800 \mathrm{mgl}^{-1}$ IBA gave the highest rooting percentage where $23.65 \pm 0.20 \%$ of cuttings was rooted when compared to other treatments. 800 $\mathrm{mg} \mathrm{L}^{-1}$ IBA treated cuttings also gave the highest mean root length per rooted cutting $(10.73 \pm 3.57 \mathrm{~cm})$, highest root dry weight per rooted cutting $(0.28 \pm 0.57)$ and the highest mean root numbers per rooted cutting where $2.50 \pm 0.92$ roots per rooted cutting were obtained (Table 2). However, the ANOVA shows that the mean root numbers per rooted cutting, mean root length per rooted cutting and root dry weight per rooted cutting are not significantly different among treatments (Table 1).
Cross sections of stem cutting at day 0 showed the normal juvenile stem organization (Fig. 4A). The cortex is multi-layered and makes up one-fifth of the stem diameter, phloem was surrounded by 2-3 layers of fibers (Fig. 4B) which also reported by Ayensu (1972), xylem consists of continuous cylinder with narrow uniseriate rays and pith composed of thick-walled cells with laticiferuous ducts. Callus was first detected in the cortex 3 weeks after cuttings were planted. Cell proliferation occurs in the cortex region near to the fibers layer and phloem (Fig. 4C). Root primordia developed from the secondary phloem with a dome-shape apex and penetrated the cortex 5 weeks after the cuttings were sowed (Fig. 4D).

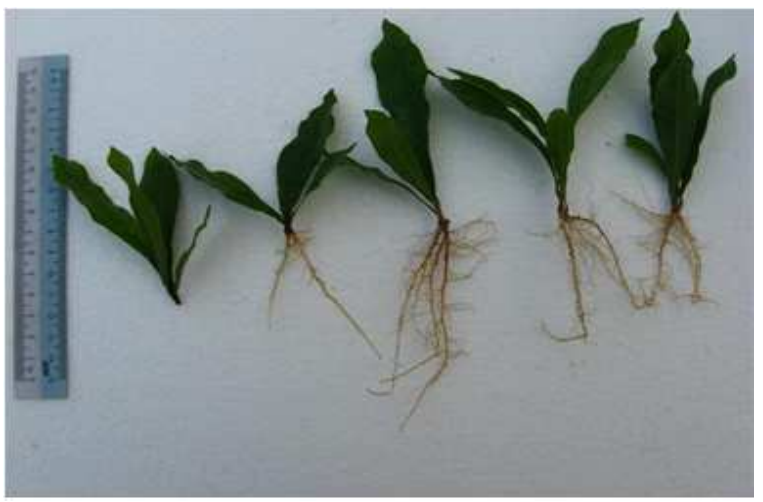

Fig. 3. Softwood miracle fruit cuttings of Synsepalum dulcificum showing sparse primary roots (from left to right: $0,200,400,600$ and $800 \mathrm{mgL}^{-1}$ IBA)

Table 1. Analysis of variance testing effects of IBA concentrations on rooting percentage, mean root numbers per rooted cutting, mean root length per rooted cutting and root dry weight per rooted cutting of softwood miracle fruit cuttings 3 months after planting

Mean square

\begin{tabular}{llll}
$\begin{array}{l}\text { Sources } \\
\text { of variation }\end{array}$ & $\begin{array}{l}\text { Rooting } \\
\mathbf{( \% )}\end{array}$ & $\begin{array}{l}\text { No. of roots } \\
\text { per rooted cutting }\end{array}$ & $\begin{array}{l}\text { Root length } \\
\text { per rooted cutting }\end{array}$ \\
\hline Block & $0.8821 \mathrm{~ns}$ & $0.5395 \mathrm{~ns}$ & $0.6894 \mathrm{~ns}$ \\
IBA concentrations & $0.0988 *$ & $0.4059 \mathrm{~ns}$ & $6.2067 \mathrm{~ns}$ \\
\hline
\end{tabular}

Values followed by * are significant at $\mathrm{p}<0.05$. Values followed by $n s$ are non significant at $\mathrm{p}<0.05$

Table 2. Rooting percentage, mean root numbers per rooted cutting, mean root length per rooted cutting and root dry weight per rooted cutting of softwood miracle fruit cuttings under different IBA concentrations

\begin{tabular}{llccc}
\hline $\begin{array}{l}\text { IBA } \\
\left(\mathrm{mg} \mathrm{L}^{-1}\right)\end{array}$ & $\begin{array}{l}\text { Rooting } \\
(\%)\end{array}$ & $\begin{array}{l}\text { No. of roots } \\
\text { per rooted cutting }\end{array}$ & $\begin{array}{l}\text { Root length per } \\
\text { rooted cutting }(\mathrm{cm})\end{array}$ & $\begin{array}{l}\text { Root dry weight } \\
\text { per rooted cutting }(\mathrm{g})\end{array}$ \\
\hline 0 & $0.86 \pm 0.86 \mathrm{~b}$ & $0.60 \pm 0.60 \mathrm{a}$ & $2.26 \pm 2.26 \mathrm{a}$ & $0.08 \pm 0.08 \mathrm{a}$ \\
200 & $10.04 \pm 1.88 \mathrm{ab}$ & $1.60 \pm 0.75 \mathrm{a}$ & $2.45 \pm 1.76 \mathrm{a}$ & $0.12 \pm 0.08 \mathrm{a}$ \\
400 & $0.86 \pm 0.86 \mathrm{~b}$ & $0.80 \pm 0.80 \mathrm{a}$ & $2.80 \pm 2.80 \mathrm{a}$ & $0.14 \pm 0.14 \mathrm{a}$ \\
600 & $13.14 \pm 0.86 \mathrm{ab}$ & $2.20 \pm 0.86 \mathrm{a}$ & $7.62 \pm 3.35 \mathrm{a}$ & $0.25 \pm 0.12 \mathrm{a}$ \\
800 & $23.65 \pm 0.20 \mathrm{a}$ & $2.50 \pm 0.92 \mathrm{a}$ & $10.73 \pm 3.57 \mathrm{a}$ & $0.28 \pm 0.57 \mathrm{a}$ \\
\hline
\end{tabular}

Mean values \pm Standard Error (S.E.). Mean values followed by the same letter within a column are not significantly different ( $\mathrm{p} \leq$ 0.05 using Duncan Multiple Range Test) 


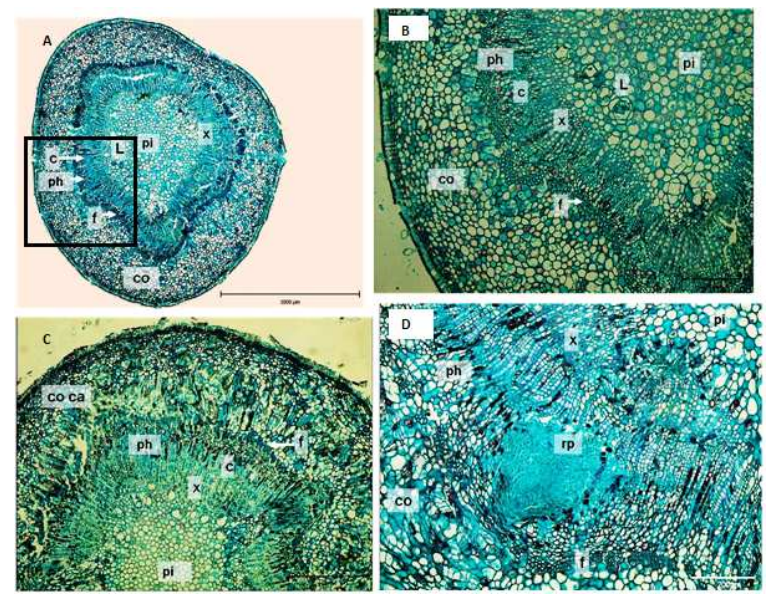

Fig. 4. Cross section of stem of Synsepalum dulcificum: (A) at day 0 under 40x magnification. Boxed region appears in (B) at 200x magnification, illustrating fibers layer (f), phloem (ph), pith (pi), laticiferous duct (L), xylem (x) and vascular cambium (c). (C) Illustrating callus (ca) occurred in cortex (co) near the fibers layer and phloem at week 3 under 100x magnification. (D) Illustrating root primordial (rp) with a dome-shape apex developed from the secondary phloem and penetrated the cortex layer at week 5 under $200 x$ magnification. Scale bars: $\mathrm{A}=1000 \mu \mathrm{m}, \mathrm{B}$ and $\mathrm{D}=200 \mu \mathrm{m}$ and $\mathrm{C}=500 \mu \mathrm{m}$

\section{DISCUSSION}

The miracle fruit cuttings obtained from matured plants produced flower buds throughout the study period. Flower development can serve as a competing sink to the detriment of rooting (Hartman, 2002). Flowering capacity of cuttings indicates the maintenance of mature state and lack of rejuvenation of cuttings (Kesari et al., 2009). Rooting potential of the cuttings in woody tree species is a juvenile characteristic and the rooting capacity declines when the tissues in the cuttings unable to rejuvenate (Kibbler et al., 2004). A micro propagation study conducted by Ogunsola and Ilori (2008) indicated that it was difficult to induce rooting of Synsepalum dulcificum through nodal explants from mature plants and seedlings. They suggested that this attribute to the difficulty in rejuvenating mature tissues of woody species.

Auxin plays an important role in adventitious root development on cuttings. Successful adventitious root formation and development of cuttings are highly depending on endogenous and exogenous auxin levels (Kochhar et al., 2005; Ludwig-Muller, 2000). Synthetic auxin application on cuttings has been found to increase rooting percentage and number of adventitious roots per rooted cutting (Kesari et al., 2009; Patricio et al., 2006). Indole-3-Butyric Acid (IBA) has been proven effective on propagation of woody tree species (Kesari et al., 2009; Patricio et al., 2006; Elkhalifa and Al-Mufarrij, 2006; Amissah et al., 2008). Previous studies showed that the rooting percentage increased with the increasing of IBA concentrations (Kesari et al., 2009; Lemay et al., 2009). Such pattern was observed in this study where softwood miracle fruit cuttings treated with high concentration of IBA give higher rooting percentage. Synsepalum dulcificum is a difficult-to-root plant (Duke and DuCellier, 1993). According to Hartman (2002), difficult-to-root plants lack of rooting morphogens and/or the cells are not responding to the morphogens even though natural auxin may or may not present in ample amount. Exogenous auxin application on the cuttings gives little or no rooting enhancement. Presence of physical barriers could inhibit the adventitious root emergent in difficult-to-root plant (Beakbane, 1961; Edwards and Thomas, 1980). In difficult-to-root species, dead sclerenchyma cells surrounded between the phloem and cortex in the stem and the sclerenchyma ring develops as the stem matures and gets older. It was found that impenetrable sclerenchyma ring could act as a barrier to block root emergence (Hartman, 2002). A study conducted by Amissah et al. (2008) indicated that cell expansion and proliferation in cortex, phloem and cambium able to break the continuous layer of sclerenchyma tissue. In this study, fiber layers found around the phloem of softwood miracle fruit stem act as a barrier to block root emergence from the phloem. However, IBA application found to be able to promote cell expansion and proliferation in cortex which subsequently break the fiber layers.

\section{CONCLUSION}

Synsepalum dulcificum is a difficult-to-root tree species. Lack of rejuvenation of mature tissues in stem cuttings reduce the rooting capability of miracle fruit. However, present study showed that $800 \mathrm{mg} \mathrm{L}^{-1}$ of IBA treatments were effective in increasing the rooting percentage of miracle fruit cuttings. For the adventitious roots initiation and development of miracle fruit softwood cuttings, root primordial was found developed from the secondary phloem and surrounded by fiber layers which could hinder its emergence. However, IBA applications promote cell expansion and proliferations which able to break the fiber layers and allowed the root primordial to emerge. 


\section{ACKNOWLEDGEMENT}

This research was funded by the Ministry of Higher Education of Malaysia under the Fundamental Research Fund Scheme (FRGS), project number: 01-01-07-092FR.

\section{REFERENCES}

Amissah, J.N., Jr. D.J. Paolillo and N. Bassuk, 2008. Adventitious root formation in stem cuttings of Quercus bicolor and Quercus macrocarpa and its relationship to stem anatomy. J. Am. Soc. Hort. Sci., 133: 479-486.

Ayensu, E.S., 1972. Morphology and anatomy of Synsepalum dulcificum (Sapotaceae). Bot. J. Linn Soc., 65: 179-187. DOI: 10.1111/j.10958339.1972.tb00932.x

Beakbane, A.B., 1961. Structure of the plant stem in relation to adventitious rooting. Nature, 192: 954955. DOI: $10.1038 / 192954 \mathrm{a} 0$

Duke, J.A. and J.L. DuCellier, 1993. CRC Handbook of Alternative Cash Crops, 1st Edn., CRC Press, Boca Raton, Florida, ISBN: 0849336201, pp: 536.

Edwards, R.A. and M.B. Thomas, 1980. Observations on physical barriers to root formation in cuttings. Plant Propagator, 26: 6-8.

Elkhalifa, K.F. and H. Al-Mufarrij, 2006. Propagation of Cordia mixa L. by stem cuttings. Pak. J. Biol. Sci., 9: 176-178.

Hartman, H.T., 2002. Plant Propagation: Principles and Practices. 6th Edn., Prentice-Hall, India, ISBN-10: 0132061031, pp: 770.

Johansen, D.A., 1940. Plant Microtechnique. 1st Edn., McGraw-Hill Book Company Inc., New York, London, pp: 523.

Joyner, G., 2006. The Miracle Fruit. In: Quandong Magazine of the West Australian Nut and Tree Crop Association, Scott, P., (Ed.)., West Australian Nut and Tree Crop Association Subiaco, West Australia, pp: $15-15$.

Kant, R., 2005. Sweet proteins-potential replacement for artificial low calorie sweeteners. Nutr. J., 4: 5-5. DOI: $10.1186 / 1475-2891-4-5$
Keay, R.W.J., 1992. Trees of Nigeria. 1st Edn., Clarendon Press, Oxford, United Kingdom, pp: 476.

Kesari, V., A. Krishnamachari and L. Rangan, 2009. Effect of auxins on adventitious rooting from stem cuttings of candidate plus tree Pongamia pinnata (L.), a potential biodiesel plant. Trees-Structure Function, 23: 597-604. DOI: 10.1007/s00468-0080304-x

Kibbler, H., M.E. Jhonston and R.R. Williams, 2004. Adventitious root formation in cuttings of Backhousia citriodora F. Muell: 1. Plant genotype, juvenility and characteristics of cuttings. Sci. Horticul., 102: 133-143. DOI: 10.1016/J.SCIENTA.2003.12.012

Kochhar, V.K., S.P. Singh, R.S. Katiyar and P. Pushpangadan, 2005. Differential rooting and sprouting behaviour of two Jatropha species and associated physiological and biochemical changes. Curr. Sci., 89: 936-939.

Lemay, V., G. Gateble and S. McCoy, 2009. Vegetative propagation of two endemic species of Cloezia Brongn. And Gris for conservation and mining revegetation activities in New Caledonia. New Forests, 37: 1-8. DOI: 10.1007/s11056-008-9103-x

Ludwig-Muller, J., 2000. Indole-3-butyric acid in plant growth and development. Plant Growth Regul., 32: 219-230. DOI: $10.1023 / \mathrm{A}: 1010746806891$

Ogunsola, K.E. and C.O. Ilori, 2008. In vitro propagation of miracle berry (Synsepalum dulcificuDaniel) through embryo and nodal cultures. Afr. J. Biotechnol.

Opeke, L.K., 1982. Tropical Tree Crops. 1st Edn., John Wiley and Sons Ltd., United Kingdom, pp: 312.

Patricio, H.P., Y.T. Castaneto, A.P. Vallesteros and E.T. Castañeto, 2006. Macropropagation of Shorea guiso using stem cuttings. J. Tropical Forest Sci., 18: 198-201.

Temussi, P.A., 2006. Natural sweet macromolecules: How sweet proteins work. Cellular Mol. Life Sci., 63: 1876-1888. DOI: $10.1007 / \mathrm{s} 00018-006-6077-8$ 